\title{
Assessment of drivers and dynamics of gully erosion in case of Tabota Koromo and Koromo Danshe watersheds, South Central Ethiopia
}

\author{
Getahun Hassen ${ }^{1 *}$ and Amare Bantider ${ }^{2,3}$
}

\begin{abstract}
Globally erosion has been considered as an environmental and agricultural problem since the first agricultural revolution. In Ethiopia gully erosion has been recorded as a very serious and common socio-economic and environmental problem of several watersheds. Therefore, the objective of this research was to assess the drivers, dynamics and impacts of gully erosion in case of Tabota Koromo and Koromo Danshe watersheds, South-Central Ethiopia. The intended objectives were achieved by triangulating the image analysis with the data obtained from GPS, group discussion, interview, house hold survey, field observation and field measurement. The result of the study indicated that gully erosion was initiated in the steep slope following the 1970s and 1980s land cover change and other anthropogenic factors. In addition, the soil properties and steep slope (gravity) of the land have contributed in exacerbating the problems. Gully erosion caused physical, social and economic impacts in the area. According to the participants on group discussion and interview, the socio-economic impacts of gully erosion were loss of life for a 12 year boy, injuries of five live stocks, and decline of yields throughout the year. Result from field measurement and observation depicted that loss of soil $\left(1,080,782.6 \mathrm{~m}^{3}\right)$ and loss of biodiversity are the major physical impacts of gully erosion. Yet there are promising conditions to rehabilitate the gullied area for sustainable ecosystem services in the watersheds. These promising conditions are the availability of high labour forces, access of transportation, civic societies working on natural resource conservation and the green economy development policy of the country. Therefore, concerned government bodies and the local communities at different level need to set plan and work for implementation in a way to use the existing opportunities.
\end{abstract}

Keywords: Gully erosion, Dynamics, Drivers, Impacts, Rehabilitations

\section{Introduction}

Soil erosion is one of the natural processes which have lasted for a long period of time (Parikh and James 2012). Natural soil erosion will take place at a given place with normal rate, but the equilibrium conditions mainly change due to anthropogenic factors (Vijith and Dodge-Wan 2019). Though, historical documentation is lacking how soil erosion has been perceived, scholars argue soil erosion had already been in earlier prehistoric times. However, since the Neolithic period agricultural activities have

\footnotetext{
*Correspondence: getahunhassen5@gmail.com

${ }^{1}$ Department of Natural Resource Management, College of Agriculture, Dilla University, Dilla, Ethiopia

Full list of author information is available at the end of the article
}

allowed human being to modify the natural environment (Dotterweich 2015).

Loss of soil is one of the most challenging global environmental problems (Tebebu et al. 2010). According to El-Swaify (1994) soil degradation via water erosion accounted for about $55 \%$ or 2 billion ha in the world. Moreover soil erosion is very sensitive to both natural and human factors (Pimentel and Burgess 2013). Among different forms of soil erosion, gully erosion is an environmental threat throughout the world. And its effect on soil, land functions and sediments is attracting attention from scientists (Ionita et al. 2015).

The major driving forces for gully erosions are high population growth, poor rangeland, lack of vegetation 
cover, overgrazing, intensive and short-period rainfall, improper land use (cultivation on steep slopes), improper irrigation design, wrong discharge of water in the channels, and soil characteristics (Jahantigh and Pessarakli 2011; Tamene and Vlek 2008).

Gully form of soil erosion causes extensive socioeconomic and environmental impacts, and most of them are negative (Valentin et al. 2005; Marzolff et al. 2011). According Zgłobicki et al. (2015) gully erosion decreases the agricultural land, farm productivity/crop yields and grazing land. Also gully-based valley sediment yield accounted for 10 to $94 \%$ of the total watershed sediment yield (Poesen et al. 2003).

In Ethiopia dense gully erosion is typical parts of the landscape (Gebrehiwet 2004; Frankl et al. (2010). According to the Hurni (1988) estimation the average erosion rate in infertile crop land are 70 tons / ha / year. Yet the CRSPT, U. (2000) report has indicated that, the average annual rate of soil loss in Ethiopia is estimated to be 12 tons/ ha /year and it can be greater than 300 tons/ha/year on steep slopes where vegetation coverage is little.

Particularly in the highland area loss of top soil via gully erosion reach over 1.5 billion tons, this amount of loss could have added about 1.5 million tons of grain to the country's harvest (Tamene and Vlek 2008; Taddese 2001). Due to soil erosion problem the national average yields for maize, sorghum, and finger millet are 3.0, 2.0 and $1.7 \mathrm{t} \mathrm{ha}^{-1}$, respectively in $2012 / 2013$. This amount of yield is the lowest in the world and unable to meet the basic food needs of the population (Bewket 2007).

Agricultural based economy and widespread problem of soil erosion in Ethiopian has made natural resources management, particularly soil and water conservation practices the major area of interest in the country. Though, massive reforestation and modern soil and water conservation schemes were launched before 49 years the impacts were far below expectations and land degradation continued as problem (Demeke 2003).

There are several factors for the less effect of the past conservation activities in Ethiopia. Failure to balance land management interventions with the dynamic nature of land degradation is the major factor for small-holder farmers to sustain both economic and environmental issues (Shiferaw and Holden 1999; Gessesse et al. 2009).

This implies to the soil conservation activities primarily need to look for identifying drivers and dynamics of a site level gully erosion based on scientific and systematic ways before taking treatment measure. Because it gives chance to design suitable and effective gully controlling activities. Therefore, the objectives of this research were to assess drivers, dynamics and effects of gully erosion in case of Tabota Koromo and Koromo Danshe watersheds South Central Ethiopia.

\section{Study area}

The study watersheds are located in south central rift valley areas of Ethiopia at about $285 \mathrm{~km}$ from Addis Ababa. The south central rift valley region of Ethiopia is part of the Great East African Rift Valley. It originates from Arabian Plate in the Middle East and traversing longitudinally in the eastern African countries, such as Djibouti, Eritrea, Ethiopia, Kenya, Uganda,Tanzania, and Mozambique (Ayenew 2007).

The watersheds are situated at $7^{0} 3^{\prime}$ to $7^{0} 6^{\prime}$ north latitude and $38^{\circ} 19^{\prime}$ to $38^{\circ} 23^{\prime}$ East longitudes with total areas of about $8 \mathrm{~km}^{2}$ (MoWR 2009) see Fig. 1. The rift valley area of Ethiopia is characterized by very dynamic and fragile landscapes (Bekele et al. 2018). The watersheds are distinguished by highly dissected and non vegetated mountain terrain with big gullies that run down the steep slope (EOSA 2007).

Climate of the area characterized by the annual rain fall ranges from 700 to $1200 \mathrm{~mm}$ and the mean annual temperature range between $18-21^{\circ} \mathrm{c}$. The rain fall is characterized by dry, cold and windy winter and warm and wet summer (Mechal et al. 2015). And the agroclimatic zone of the area falls within dry mid altitude category. There is no perennial river and the only water resource available is Lake Hawassa, one of the biggest lakes within the rift valley.

According to Ministry of Water Resources (2009) the soil type which is dominantly covered the watershed are young and not well consolidated Cambisol, and highly hydrated dried Andosols. These soils are characterized as weak soil horizon, fine textured material, reduce infiltration, increase runoff and easily remove with surface runoff water (FAO 2006). The soil types of the study watersheds combined with the steep topography, poor land cover and anthropogenic factors are highly contributing for the gully formation and expansion in the area.

The major economic activities of the watersheds are agriculture (mixed farming) that covers around $83 \%$ and the rest are small trades and labour hiring. In the area cultivation practice lasted for long time in which almost all potential lands are put under crop cover. But the problem associated with climate variability and land use and cover change causes crop failure once in every ten years and sometimes even more frequently (Ministry of Water Resources 2011).

\section{Methodology}

The formulated objectives was addressed with the primary sources, such as field observation, field measurement, household survey, key informant interview, focused group discussion, aerial photo and satellite image analysis. Also the unpublished documents, archives, statistical abstracts and reports from different offices were used as secondary sources. 


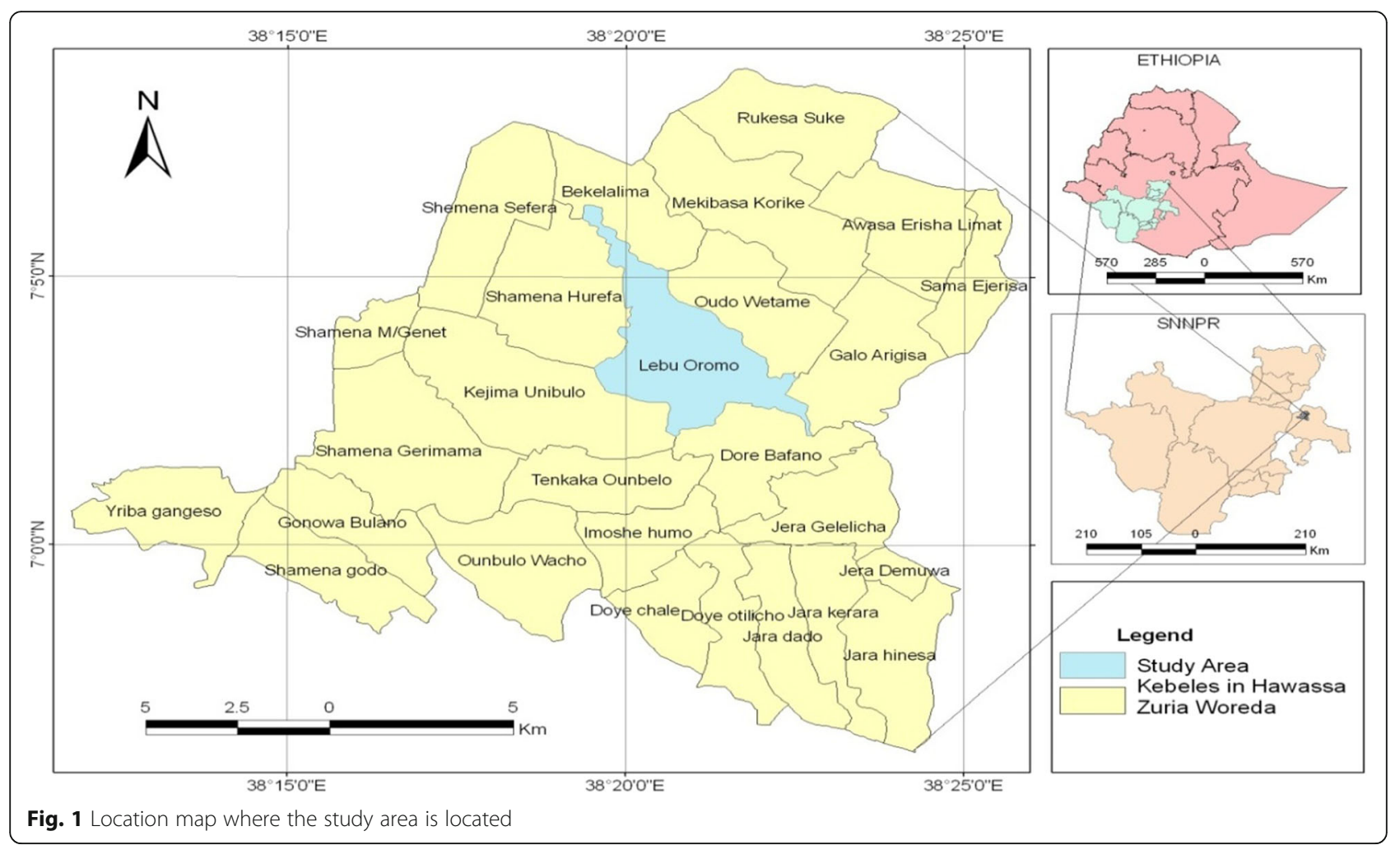

Sample size was determined using Conchran (1977) procedures.

$$
n=\frac{n_{0}}{1+\frac{\left(n_{0}-1\right)}{N}}
$$

According to this formula the total house hold population is 860

$\mathrm{n}$ at $95 \%$ confidence level and at $\pm 10 \%$ precision level $\mathrm{n}=86$

For this study the data collection activity has used mixed approach (quantitative and qualitative) and simple random sampling technique that was implemented in sequential exploratory design methods. The data for gully initiation; size (length, depth, width), density, width- depth ratio, incision period, and volume of soil loss was obtained from analysis of satellite image, aerial photo, group discussion and interview.

Whereas, the data acquisition on gully drivers, impacts and opportunities for rehabilitation were carried out with field observation, household survey, group discussion and key informant interview. Identification of gully age and historical development was obtained from monitoring event calendar and reference time approach of (Moges and Holden 2008). In this regard elders and community leaders were purposefully selected to give the major event which could serve to guess the age of each gully (Table 1).Based on Table 1 the average gully age was estimated, which is important in the attempt of calculating the volume of soil loss from each gully since its onset. The volume of soil loss estimation of the study

Table 1 Event calendar used to monitor gully age estimate

\begin{tabular}{ll}
\hline Year & Event calendar used to monitor gully age estimation \\
\hline 1974 & Overthrow of Emperor Hailesellasie \\
1977 & Sinkale clash, the fight between neighbouring Sidama and Arsi Oromo of the study area Or it is after three years of Dergue come to power. \\
1979 & Wege clash, the fight between neighbouring Sidama and Arsi Oromo of the study area. Or after five years of Dergue come to power. \\
1988 & Villagisation (resettlement) program. Before three years of the overthrow of military government \\
1996 & Toge clash, the fight between neighbouring Sidama and Arsi Oromo of the study area. After six years of the FDRE come to power \\
& Field measurement result of each gullies
\end{tabular}


Table 2 Perceptions of HHR on the drivers of gully erosion

\begin{tabular}{|c|c|c|c|c|c|}
\hline \multirow[t]{2}{*}{ Factors of gully erosion } & \multicolumn{2}{|c|}{ Tabota Koromo } & \multicolumn{3}{|c|}{ Koromo Danshe } \\
\hline & Respondents & Precent & Respondents & Precent & Average $\%$ \\
\hline Human factor & 13 & 34.2 & 16 & 33.3 & 34 \\
\hline Natural factor & - & - & 1 & 2.1 & 1 \\
\hline Both human and natural factors & 25 & 65.8 & 31 & 64.6 & 65 \\
\hline Total & 38 & 100.0 & 48 & 100 & 100 \\
\hline
\end{tabular}

Source House hold survey

watershed has been used with Field Office Technical Guide/ FOTG (2002) formula of soil loss estimation as equation number 1 and 2 .

$$
\mathrm{V}=\mathrm{Lx}\left[\left(\mathrm{W}_{\mathrm{t}}+\mathrm{W}_{\mathrm{h}}\right) / 2\right] \times \mathrm{Df}
$$

Where $\mathrm{L}=$ the total length in meter

$\mathrm{W}_{\mathrm{t}}=$ the average top width in meter

$\mathrm{W}_{\mathrm{b}}=$ the average bottom width in meter

$\mathrm{D}_{\mathrm{f}}=$ the average depth measured in meter

$\mathrm{V}=$ the displaced volume in cubic meter

To convert this calculated volume to a weight of soil lost over time (tones/year) equation 2 was used.

$$
\mathrm{E}=[(\mathrm{VxW} / 1000) / \mathrm{Y}] \times \mathrm{N}
$$

Where $\mathrm{E}=$ the soil loss in tons per year

$\mathrm{V}=$ the volume in cubic meter calculated above

$\mathrm{W}=$ the average weight of soil in kilogram per cubic meter (Bulk density)

$1000=$ the weight in kilogram per tone

$\mathrm{Y}=$ the numbers of years the gully has been active

$\mathrm{N}=$ the number of similar classic gullies

The other important element on gully dynamics assessment is the soil bulk density, this data was obtained from earlier work in the watersheds. According to Abdurrahman (2012) the average soil bulk density of soil of the study watersheds is $0.97 \mathrm{~g} / \mathrm{cm}^{3}$. This result is consistent with Moges and Holden (2008) in neighbouring watershed, where the average soil bulk density ranges from 0.90 to $1.06 \mathrm{~g} / \mathrm{cm}^{3}$. Therefore the soil bulk density of the study watersheds is $0.97 \mathrm{~g} / \mathrm{cm}^{3}$.

\section{Data analysis and interpretation}

Data were computed and analysed with a combination of different techniques. The drivers, dynamics and impacts of gully erosion identification was carried with analysis of GIS based data processing, topographic map of the 1976, aerial photographs of 1965 and 1972 and the spot satellite image of 2006. Topographic map with the scale of 1:50,000 were used as a base map in order to geo-reference the satellite image and aerial photos. In addition, it was also used to extract contour lines to analyse the slope, and change in length, width and spatial distribution of gullies for the reference years of 19722006.

To perform analysis of gully pattern and spatial distribution the steps below were properly carried out.

Step1, Scanning; after purchasing the topographic map and aerial photos from Ethiopian Mapping Agency (EMA), it was converted from analogue to digital' format.

Step 2, Geo-referencing; in this stage two type of image registration was made; the first is image to map registration, which was inserting the coordinates manually to geo reference the GIS data for the topographic map. The second is image to image registrations; it was applied to geo reference the satellite image by using the map as a reference. Similar technique was used for aerial photos with support of georeferenced satellite image as a base. Both type of

\begin{tabular}{|c|c|c|c|c|c|}
\hline \multirow{2}{*}{$\begin{array}{l}\text { Type of land cover change } \\
\text { From forest or grazing land to resident }\end{array}$} & \multicolumn{2}{|c|}{ Tabota Koromo } & \multicolumn{3}{|c|}{ Koromo Danshe } \\
\hline & 7 & 18.4 & 9 & 18.7 & 19 \\
\hline From forest to bare land & 1 & 2.6 & 1 & 2.1 & 2 \\
\hline From forest and grass to cultivated land & 30 & 79 & 36 & 75 & 77 \\
\hline I have no opinion & - & - & 2 & 4.2 & 2 \\
\hline Total & 38 & 100.0 & 48 & 100.0 & 100 \\
\hline
\end{tabular}

Table 3 Awareness of the people on land cover change of the area

Source House hold survey 

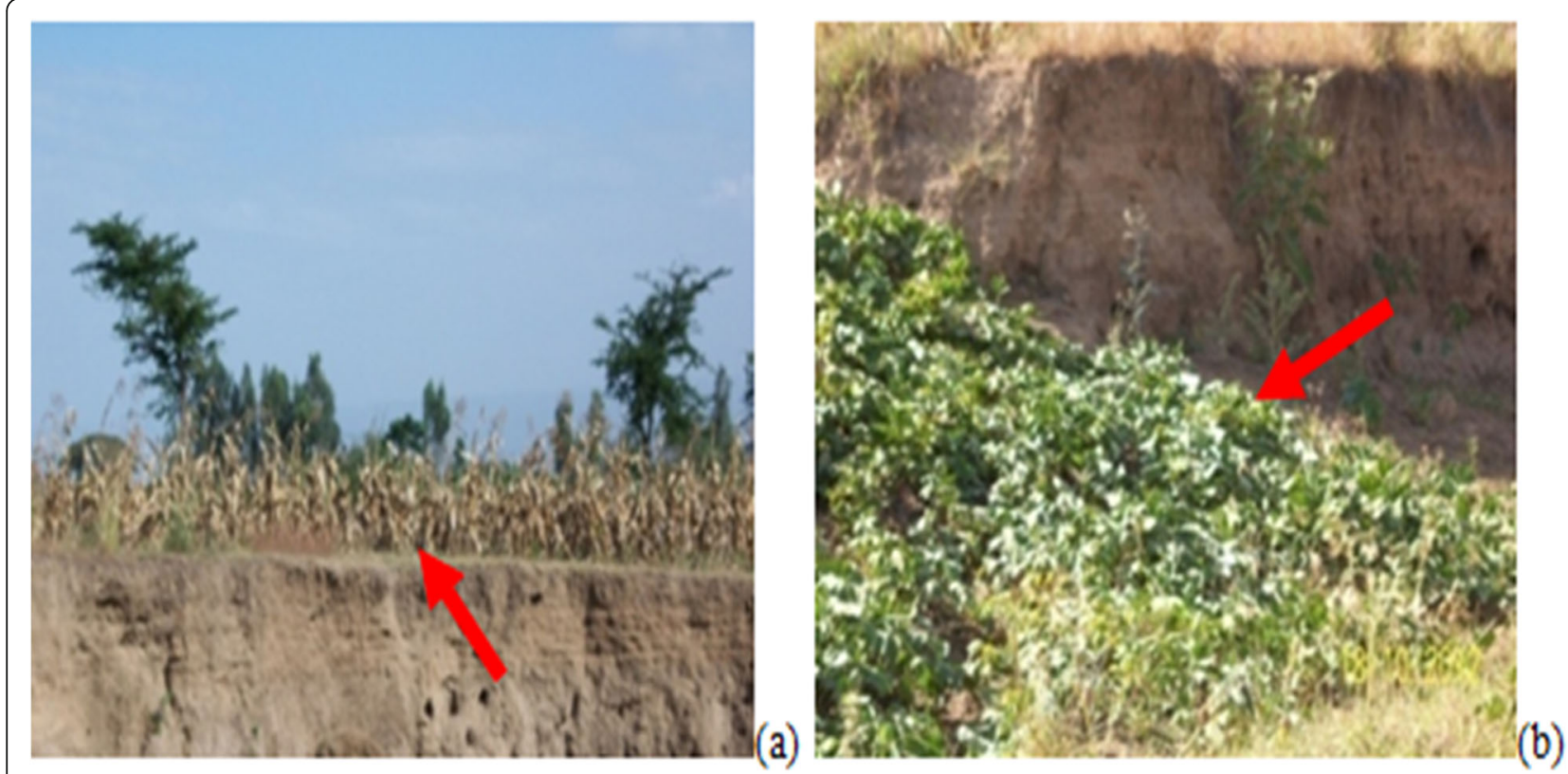

Fig. 2 Gully bank and gully bottom cultivation from left to right

image registration were performed using the image processing software of ENVI 4.3.

Step 3, Digitizing was carried out in ARC GIS 9 and Arc Map version 9.3.This step is helpful to extract contour lines from the scanned topographic map and to map time serious gullies from the satellite image and scanned aerial photos. Finally, the digitized contours and gullies were exported as graphics so as to be incorporated in the result and discussion part.

For the data obtained from interview, group discussion, field observation and secondary sources content analysis technique was used. This technique is important to assess the socio-economic characteristics of households and their perceived responses on drivers, dynamics and impacts of gully erosion. The quantitative data that was obtained through household survey, field measurement, and different secondary sources analysed by descriptive statistics using computer software statistical package for social science (SPSS) version 20.

\section{Result and discussions \\ Drivers of gully erosion}

The data on driving force of gully erosion was obtained from house hold survey questions and field observation (see Table 2).

According to Table 2 from the total house hold respondent about $34 \%$ of the participants were responded the human activities are factor for gully initiation in their village. The majority about (66\%) were perceived that the driver of gully erosion has the result of both human and natural factors. This finding is in agreement with (Konana et al. 2017; Valentin et al. 2005).

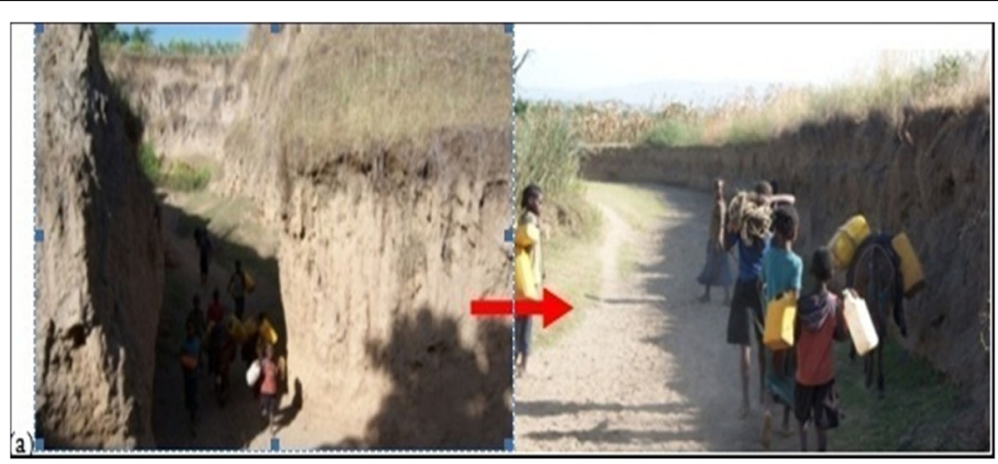

Fig. 3 Local people using the gully channel for foot way 


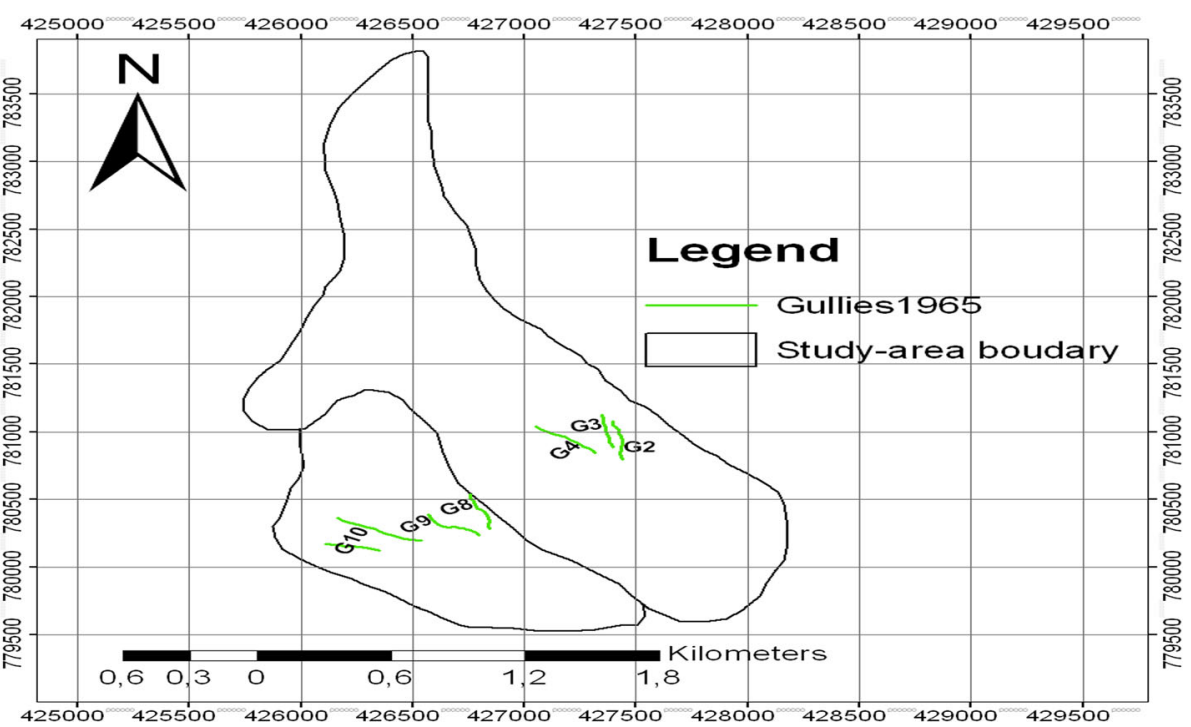

Fig. 4 Pattern and location of gullies in 1965

\section{Human activities as drivers of gully erosion}

According to the farmers in the watersheds formation and development of gullies were related with sociopolitical factors, high population number and associated human activities. According to the participants the major human activities that caused gully erosion in the watersheds are land cover change (deforestation), improper irrigation design, wrong discharge of water, expansion of agricultural land, overgrazing, improper land use (steep slopes cultivation, farming close to the gully bank and gully floor) which was in line with (Valentin et al. 2005, and Lal 2001 cited in Jones et al. 2008).
In the Table 3 of the total respondents $77 \%$ have said that land cover has changed from forest and grass land to cultivated land (production of crops) particularly since the 1970s. For instance; Fig. 2 shows that, the farmers who are settled near the gully have been cultivating the gully bank close to $50 \mathrm{~cm}$ and some others were ploughing the gully floor. As mentioned above mixed farming accounts about $86 \%$ of the watersheds economic activities.

Therefore, this economic activity combined with the agricultural activities as shown in Fig. 2 highly initiate gully formation, gully bank collapse, gully expansion and

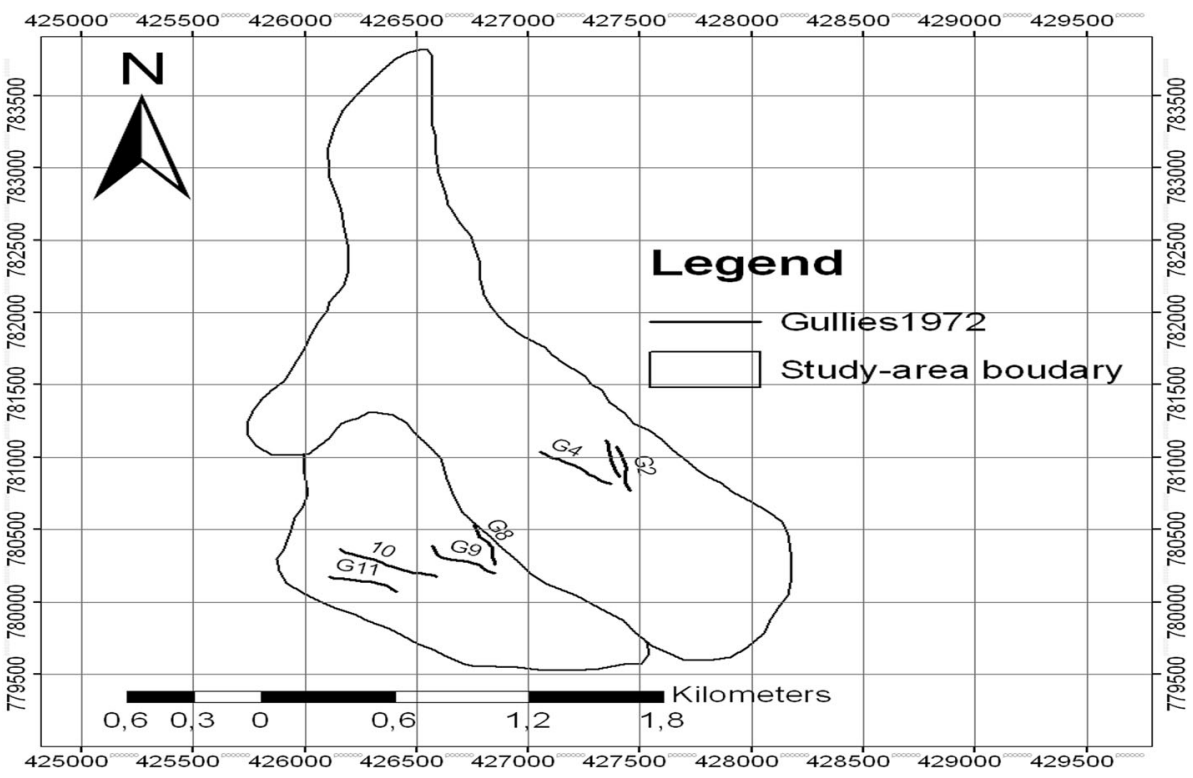

Fig. 5 Pattern and location of gullies in 1972 


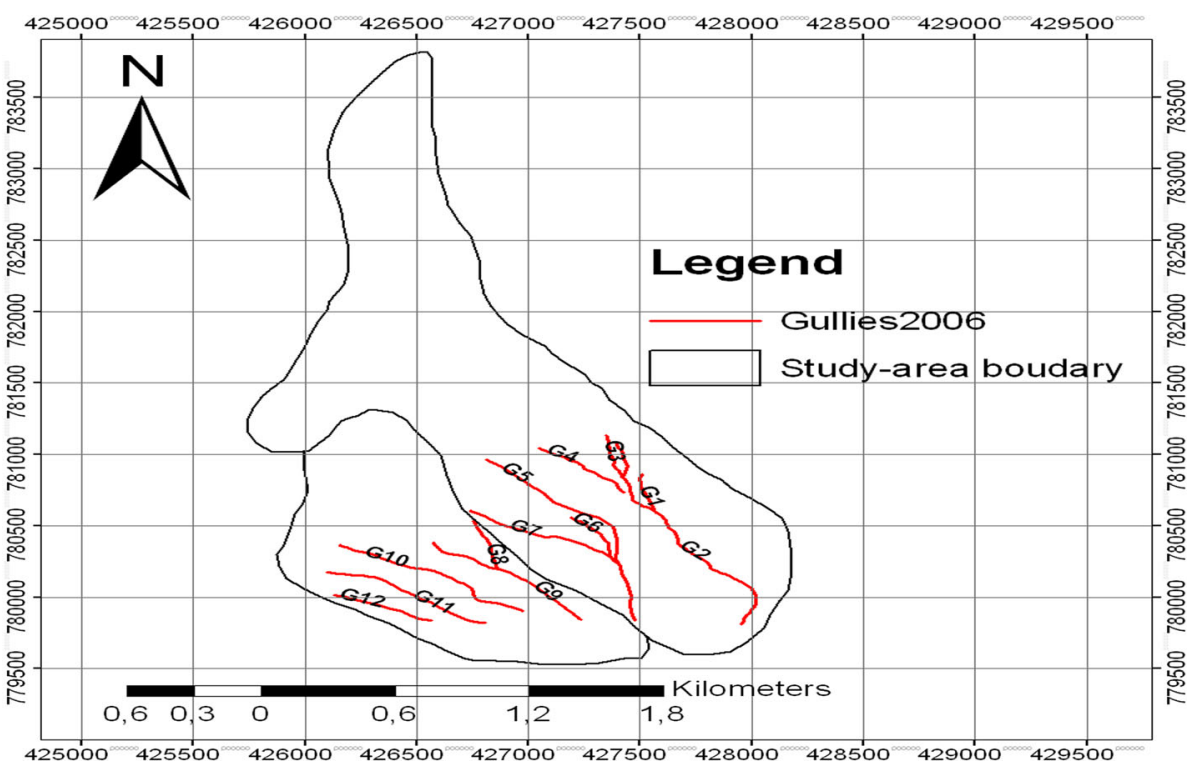

Fig. 6 Pattern and location of gullies in 2006

limit natural stabilization. Fortunately during field observation the researchers had got a chance to observe the local children and animals walking on the bottom of the gully (Fig. 3).

These activities of the community also have a chance to expose the soil to different agent of erosion either water or wind and also it reduced the possibility of natural rehabilitation. The other threat of the Fig. 3 beyond soil erosion is a sudden gully bank collapse (mass failures) that will cause injuries or loss of human and animals' life.
Natural factors as a drivers of gully erosion

Natural drivers of gully erosion are mainly heavy rain fall, high temperature and steep slope /gravity factor (Frankl 2012; Faulkner et al. 2004). The data obtained from survey question, group discussion and interview were confirmed this facts. According to the participants the natural drivers of gully erosion of the study area are loss of vegetation cover, weak soil structure, steep slope, high intensity of summer rain, and frequent droughts.

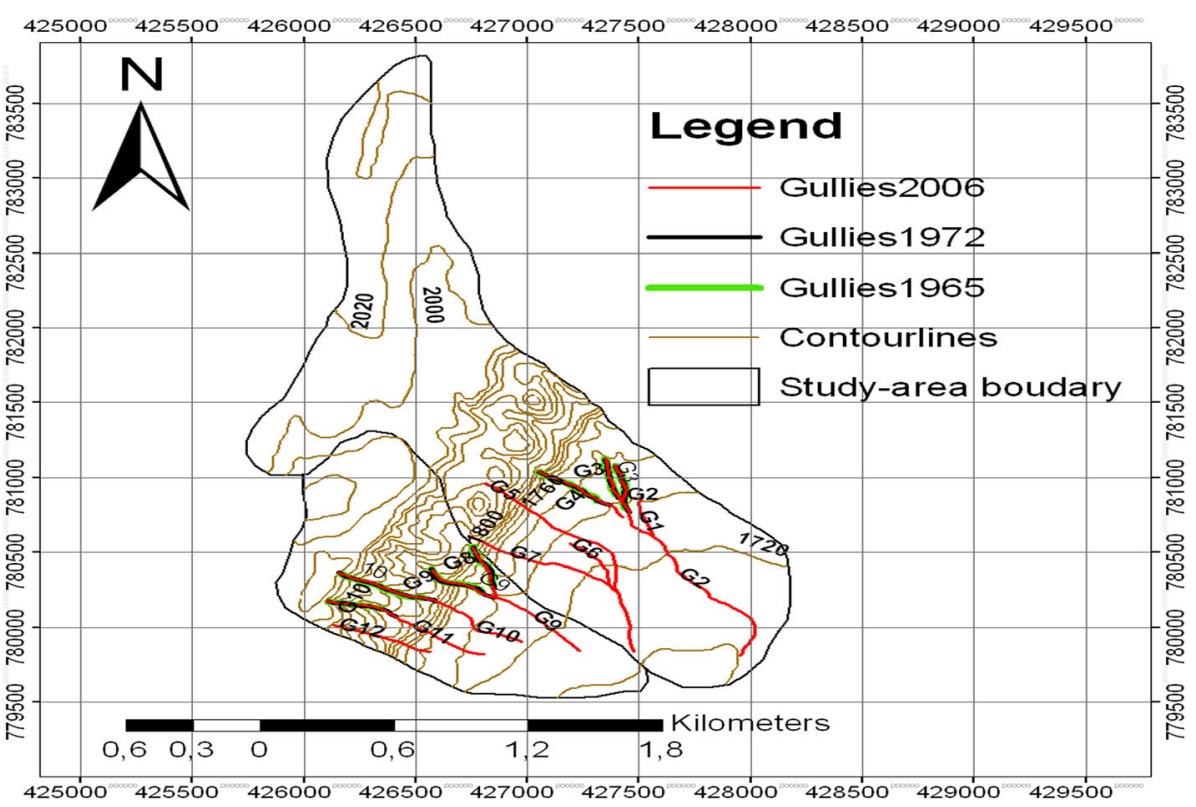

Fig. 7 "Overlaid maps" gully map 
Table 4 Size of gully length, and width from 1965-2012

\begin{tabular}{|c|c|c|c|c|c|c|c|c|c|}
\hline \multirow{2}{*}{$\begin{array}{l}\text { Gully } \\
\text { ID }\end{array}$} & \multicolumn{2}{|l|}{1965} & \multicolumn{2}{|l|}{1972} & \multicolumn{2}{|l|}{2006} & \multicolumn{3}{|c|}{ Field measurement } \\
\hline & Length $(\mathrm{m})$ & Width (m) & Length $(\mathrm{m})$ & Width (m) & Length/m & Width (m) & Length $(\mathrm{m})$ & Width (m) & Depth/m \\
\hline$\overline{G 1}$ & NG & NG & NG & NG & 255 & 10 & 263 & 13 & 10 \\
\hline G2 & 295 & 9 & 317 & 11 & 1531 & 22 & 1559 & 28 & 15 \\
\hline G3 & 226 & 6 & 232 & 7.5 & 320 & 11 & 355 & 12 & 11 \\
\hline G4 & 337 & 6 & 386 & 7 & 472 & 17 & 480 & 22 & 9 \\
\hline G5 & $N G$ & $N G$ & $N G$ & NG & 1416 & 12 & 1541 & 13 & 11 \\
\hline G6 & NG & NG & NG & NG & 398 & 6 & 550 & 7 & 6 \\
\hline G7 & NG & NG & NG & NG & 710 & 11 & 712 & 14 & 13 \\
\hline G8 & 281 & 8 & 303 & 10 & 573 & 13 & 600 & 13 & 9 \\
\hline G9 & 293 & 10 & 360 & 11.5 & 862 & 20 & 1055 & 25 & 9 \\
\hline G10 & 415 & 10 & 482 & 11 & 980 & 15 & 1020 & 16 & 11 \\
\hline G11 & 252 & 7 & 329 & 8.5 & 813 & 11 & 861 & 11 & 8 \\
\hline G12 & NG & NG & $N G$ & NG & 473 & 9 & 500 & 11 & 7 \\
\hline
\end{tabular}

Source: Aerial photo; satellite image and ground survey

\section{Pattern, period and origin of gully erosion}

Knowledge on gully pattern (network) serves to understand the present relation of various gullies to look back in to the history of their development and to determine the stage of development (Rowntree 1991). Based on the aerial photos of 1965/1972 and satellite image of 2006 totally 12 gullies have been identified and assigned as G1 (gully 1), G2 (gully 2), G3 (gully 3), up to Gully 12.

In the 1965 and 1972 aerial photo only 7 gullies have been identified, which are G2, G3, G4 in the Koromo Danshe micro watershed and G 8, G 9, G 10 and G11 in the Tabota Koromo micro watershed (see Figs. 4, 5, 6 and 7 and Tables 4 and 5) respectively. Image analysis of Figs. 4 and 5 were depicted similar gully pattern, origin,

Table 5 Change of gully length and width from 1965 to 2012

\begin{tabular}{|c|c|c|c|c|c|c|c|c|}
\hline \multirow{2}{*}{$\begin{array}{l}\text { Gully } \\
\text { ID }\end{array}$} & \multicolumn{2}{|c|}{$1965 \& 1972$} & \multicolumn{2}{|c|}{$1972 \& 2006$} & \multicolumn{2}{|c|}{$1965 \& 2006$} & \multicolumn{2}{|c|}{$2006 \& 2012$} \\
\hline & $\mathrm{L}$ & W & $\mathrm{L}$ & W & $L$ & W & $L$ & W \\
\hline G1 & - & - & - & - & - & - & 8 & 3 \\
\hline $\mathrm{G} 2$ & 22 & 2 & 1214 & 11 & 1236 & 13 & 28 & 6 \\
\hline G3 & 6 & 1.5 & 68 & 3.5 & 74 & 5 & 35 & 1 \\
\hline G4 & 49 & 1 & 86 & 10 & 135 & 11 & 8 & 5 \\
\hline G5 & - & - & - & - & - & - & 125 & 1 \\
\hline G6 & - & - & - & - & - & - & 152 & 1 \\
\hline G7 & - & - & - & - & - & - & 2 & 3 \\
\hline G8 & 22 & 2 & 270 & 3 & 292 & 5 & 27 & 0 \\
\hline G9 & 67 & 1.5 & 502 & 8.5 & 569 & 10 & 193 & 5 \\
\hline G10 & 67 & 1 & 498 & 4 & 565 & 5 & 40 & 1 \\
\hline G11 & 77 & 1.5 & 484 & 3 & 561 & 4 & 48 & 0 \\
\hline G12 & - & - & - & - & - & - & 27 & 2 \\
\hline
\end{tabular}

Source: Aerial photo; satellite image and ground survey Note ("NG" refers gully was not formed) size and density for the period 1965 and 1972 in the two micro watersheds. The statistical data in the Table 6, Figs. 6 and 7 shows significant increment of gully sizes between the mid 1970s and 2006. To check whether there is contributing factors or not for gully variation after 1970s, data have been collected from the elders and house hold respondents on the basis of critical period of gully erosion.In Table 6 of the total house hold representative $97 \%$ believe that the year 1970 s to 1990 s was the period of critical gully formation. This period was considered as the year of serious land cover change (deforestation) in the watersheds that was caused by power gap following overthrown of the military regime in Ethiopia (see Table 6).

Other studies conducted by Moges and Holden (2008) in the neighbouring Umbulo catchment showed that, the decisive period of gully development is estimated between 1974 and 1985. Therefore, the significant increment of gully size, density and pattern in the 2006 satellite image of the study area could have resulted from extensive removal of land cover and related factors of 1980s.

\section{Gully Morphometry and soil loss}

Knowledge on gully morphology is essential to explain the reasons for current erosion and to carry out effective gully stabilization measure (Pathak et al. 2005). Morphological characteristics of gully erosion such as gully size, rate of development, volume of soil loss, width-depth ratio (cross-sectional area) and density in the watersheds were presented in Table 7 .

To obtain the morphological data particularly about gully length and width field measurement was 
Table 6 Opinion of sample households on the period of gully expansion

\begin{tabular}{|c|c|c|c|c|c|}
\hline \multirow{2}{*}{$\begin{array}{l}\text { Critical period of } \\
\text { gully expansion }\end{array}$} & \multicolumn{2}{|c|}{ Tabota Koromo } & \multicolumn{3}{|c|}{ Kormo Danshe } \\
\hline & Respondents & Percent & Respondents & Percent & Total average \\
\hline Between $1960 \& 1980$ & - & - & 2 & 4 & 2 \\
\hline Between 1980s \&2000 & 37 & 97 & 46 & 96 & 97 \\
\hline Not known & 1 & 2.6 & - & - & 1 \\
\hline Total & 38 & 99.6 & 48 & 100 & 100 \\
\hline
\end{tabular}

Source: House hold survey

carried out in all gullies of the study watersheds (see Fig. 8). According to the Table 7 and Fig. 8 the total lengths of the gullies in the micro watersheds are $9.5 \mathrm{~km}$. Therefore, the annual average growth rate of the gully length, width, and depth of the two watersheds are $21 \mathrm{~m} /$ year, $0.275 \mathrm{~m} /$ year and $0.28 \mathrm{~m} /$ year respectively. According to (ul Rasool et al. 2011) the gully length growth rate $>10 \mathrm{~m} \mathrm{yr}^{-1}$ is considered as catastrophic type of gully development.

Hence, the average growth rate of gullies in the study watersheds with $21 \mathrm{~m} /$ year $^{-1}$ lies under catastrophic or destructive type of gully erosion. On the same topic data was collected from the house hold representatives to crosscheck their perception on morphometric result of gully development rate (see Table 8).

According to Table 8 of the total respondents approximately $70 \%$ perceive that there is fast increment of gully size and density in the area. Therefore, the result from house hold survey was indicated that perceptions of house hold representatives towards gully development are consistent with the result obtained from image analysis and field measurement.

The other gully morphometry indicators are gully density and volume of soil loss. The average gully density of the two micro watersheds is $1.4 \mathrm{~km} / \mathrm{km}^{2}$. According to Zachar (1982) and Stefanovist and Várallyay (1992) gully density classification, the result of gully density of the study area can be categorized as sever soil erosion and big gully.

For this study the amount of soil loss has estimated with the formula given by FOTG. According to the FOTG (2002) formula for soil loss estimation $\left(\mathrm{V}=\mathrm{L} \times\left[\left(\mathrm{W}_{\mathrm{t}}+\mathrm{W}_{\mathrm{b}}\right) / 2\right] \times \mathrm{Df}\right)$ the total volume of soil lost from the watersheds is $108,0782.6 \mathrm{~m}^{3}$ and the average rate of soil loss has appeared to be 6 ton/ ha /year.

\section{The effect of gully erosion}

Obviously gullies have several consequences commonly on the socio-economic and physical environment of the area where it occurred. Result obtained from house hold

Table 7 Field measurement result on gully erosion

\begin{tabular}{|c|c|c|c|c|c|c|c|}
\hline Name of watersheds & ID of the gully & Length (m) & Width (m) & Depth (m) & W/D ratio & Volume of soil lost $\left(\mathrm{m}^{3}\right)$ & Age of the gulley \\
\hline \multirow[t]{7}{*}{ Koromo Danshe Micro watershed } & G1 & 263 & 9 & 10 & 0.9 & 22,355 & 17 \\
\hline & G2 & 1559 & 17 & 15 & 1.49 & 395,206 & 50 \\
\hline & G3 & 355 & 6 & 11 & 0.7 & 26,838 & 48 \\
\hline & G4 & 480 & 13 & 9 & 1.4 & 55,944 & 48 \\
\hline & G5 & 1541 & 9 & 11 & 1.5 & $144,083.5$ & 35 \\
\hline & G6 & 550 & 5 & 6 & 0.8 & 17,490 & 20 \\
\hline & G7 & 712 & 8 & 13 & 1.1 & $75,358.08$ & 24 \\
\hline Soil loss & & & & & & $737,274.6$ & \\
\hline \multirow[t]{5}{*}{ Tabota Koromo Micro watershed } & G8 & 600 & 8.5 & 8.75 & 1.14 & 44,625 & 49 \\
\hline & G9 & 1055 & 14 & 9 & 1.6 & 135,862 & 50 \\
\hline & G10 & 1020 & 9 & 11 & 0.9 & 96,390 & 49 \\
\hline & G11 & 861 & 7 & 8 & 0.8 & 45,116 & 48 \\
\hline & G12 & 500 & 6 & 7 & 0.9 & 21,515 & 18 \\
\hline Soil loss & & & & & & 343,508 & \\
\hline Total soil loss & & & & & & $108,0782.6$ & \\
\hline
\end{tabular}




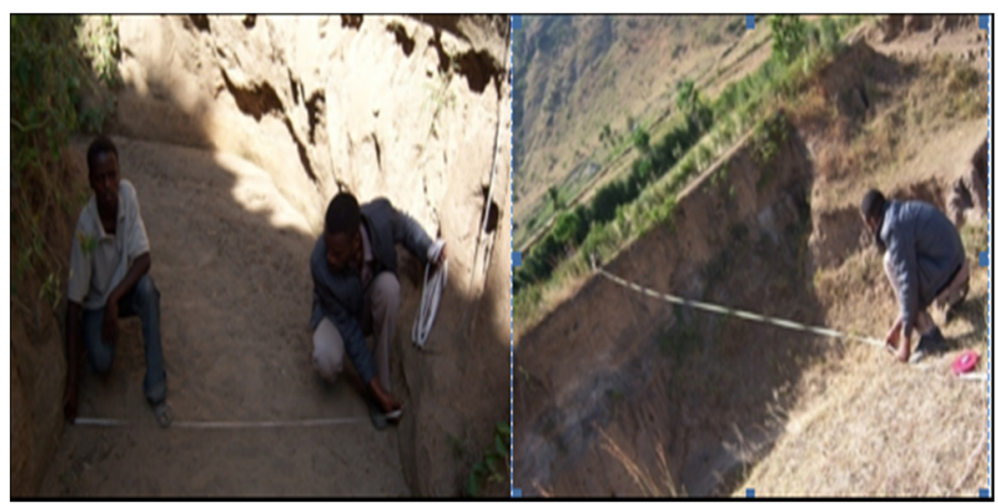

Fig. 8 Measurements of Gully Dimensions

survey, focused group discussion, interview, field observation and field measurement were showed that, the major impacts of gully erosion has listed here under the sub categories of social, economic and physical effects (see Tables 9, 10 and 11).

\section{Social effect of gully erosion}

Gully erosion has negative impact on the social aspects of human being, such as; reduce land available for agriculture, displacement of people, workload, loss of life, injuries, and risk of flooding that affects infrastructures (Valentin et al. 2005). To assess the social impacts of gully erosion, data was collected from household survey (see Table 9).

According to Table 9 about $91 \%$ of house hold respondents argued that the social effect of gully erosion in the watershed are loss of life, injuries, separation of village, out migration, insecurity, poverty and famine. For instance, participants on group discussion and interview have told that since the gully has formed around five livestock are injured and one young 12 year boy has lost his life that dropped to the deep of the gully.

Also, the farmers settled closer to the gully in the study watersheds have said that, the sound of flood in the gully during the rainy season was created a great anxiety, this condition are damaging their psyche or affecting their health condition more than other farmers far away from the gully bank.

Table 8 Perception of farmers on the rate of gully development

\begin{tabular}{lll}
\hline Rate of gully size and density increment & Frequency & Per cent \\
\hline Fast & 60 & 69.8 \\
Slow & 22 & 25.6 \\
Not identified or not known & 4 & 4.7 \\
Total & 86 & 100 \\
\hline
\end{tabular}

Source: House hold survey

\section{Economic effect of gully erosion}

Economic impact of gully erosion can be analysed from two perspectives, the first perspective is the on-site effect of plots on which the signs of runoff and erosion have developed and the second perspective is the off-site effect that damage further downstream (Boardman et al. 2003). For this research work both onsite and offsite impacts of gully erosion in the study watershed were considered for analysis (see Table 10).

The data from house hold survey (Table 10) illustrate that, around $88 \%$ of house hold representatives believes the major economic effect of gully erosion are (a) loss of property (b) decline of food and income and (c) change of livelihood system through time.

The participants have said that before the extensive gully formation the common foods items of the study area were root crops, fruits, cereal crops (maize, teff, haricot beans, barley, and green papers), and cash crops. But now most items are less productive, while some others are completely not growing because of land use land cover change, gully erosion, and related factors. During group discussion and interview very aged farmers have told to the researchers, before 1970s wild fruit was common food item to their feeding system, but now such access was become history. The result obtained from discussion, interview and observation clearly showed there are economic impacts as a result of gully formation in the study area.

\section{Environmental effect of gully erosion}

According to, Stout, B. A. (1965) gully erosion causes loss of soil forever and it affect the physical feature of the land often making them unworkable and completely uninhabitable. In the same way the physical impact of gully erosion is visibly observable in study watersheds (Table 11).

According to Table 11 around $81 \%$ of the households' respondents' have expressed that due to the dramatic expansion of gully erosion, the area has experienced land 
Table 9 Social effect of gully erosion

\begin{tabular}{lll}
\hline Social impact of gully erosion & Respondents & Percent \\
\hline Loss of human life and injuries & 7 & 8.1 \\
Increasing of poverty and famine & 1 & 1.2 \\
$\begin{array}{l}\text { Loss of life and injuries, separation } \\
\text { of village, out migration of people }\end{array}$ & 78 & 90.7 \\
$\begin{array}{l}\text { and insecurity feeling. } \\
\text { Total }\end{array}$ & 86 & 100.0
\end{tabular}

Source house hold survey

use land cover change, shortage of agricultural and grazing land, loss of fertile soil, decline of biodiversity, loss of wild life and locally known vegetation, root crops and wild fruits (see Fig. 3).

\section{Conclusions}

Watershed based knowledge of gully dynamics are more important for successful gully erosion control at least cost (Pathak et al. 2005; Poesen et al. 2011). In this regard, assessment of gully erosion dynamics, drivers and impacts in selected watersheds of South Central Ethiopia was carried out. For reliable and valid results of the study, various data gathering tools such as satellite image analysis, household survey, group discussion, interview, and field observation were applied. The results of the study showed that in 1960 s and 1970s gully erosion was constrained in the steep slope of the watersheds. But in 2006 image analysis, the gully erosion expanded significantly to the middle and lower parts of the watersheds.

According to the data obtained from the primary and secondary sources, the major driving forces of gully erosion in the study watersheds are mainly related with both human activities and natural factors. Some of the identified drivers of gully erosion of the area are change of land cover, expansion of agriculture, population growth, unconsolidated soil, steep slope (gravity factors), frequent drought and high intensity of rainfall. In the Ethiopian context high deforestation in 1970s and 1980s occurred as a result of resettlement program of the military regime, invasion of land by small famers,

Table 10 Economic effect of gully erosion

\begin{tabular}{lll}
\hline Economic impact of gully erosion & Respondents & Percent \\
\hline Decline of food & 4 & 4.7 \\
Loss of property & 2 & 2.3 \\
$\begin{array}{l}\text { Change of livelihood or economic } \\
\text { activity }\end{array}$ & 2 & 2.3 \\
$\begin{array}{l}\text { Decline of income } \\
\begin{array}{l}\text { All the above problems (loss of property, } \\
\text { change of livelihood, decline of food }\end{array}\end{array}$ & 76 & 2.3 \\
\& income) & & 88.4 \\
Total & 86 & 100.0 \\
\hline
\end{tabular}

Source house hold survey
Table 11 Physical effect of gully erosion

\begin{tabular}{lll}
\hline Physical impact of gully erosion & Respondents & Percent \\
\hline Loss of soil fertility only & 7 & 8.1 \\
Loss of vegetation only & 9 & 10.5 \\
$\begin{array}{l}\text { Loss of soil fertility, biodiversity and } \\
\text { expansion of degraded land }\end{array}$ & 79 & 81 \\
Total & 86 & 100 \\
\hline
\end{tabular}

Source house hold survey

fragmentation of lands and insecurity feeling of land users due to overthrow of the military government.

The socio-economic and environmental effects of gully erosion that has been observed in the study area were injuries and loss of life; separation of village; displacement of people; decline of products and income; loss of soil fertility and property; loss of biodiversity and wild fruits and expansion of degraded physical feature. However, there are conditions, which has good opportunity to secure the effort for gully rehabilitation and sustainable ecosystem services in the watersheds.

These are better labour force, access of transportation, positive perceptions of farmers for the gully rehabilitation, presence of different civic societies working in natural resource conservation, the national environmental policy that was drafted in 1995 and the recent integrated watershed management initiative of the country. Therefore, the result of this study will be a golden opportunities to set compatible conservation strategies for gully rehabilitation and to prevent further gully formation in the study watersheds.

\section{Recommendations}

- According to the study, land degradation via gully erosion in the watersheds are worsening throughout the year, therefore all stake holders need to apply sustainable and participatory natural resource management practices.

- Continuous' and extensive effort must be there to work with civic societies in the conservation effort.

- The high human intervention on natural resource need to be minimized or controlled.

- Awareness creation must be there about consequence of land cover change (deforestation)

- Maximum effort must be given to conserve the remaining natural resources.

- Research based conservation design need to be prepared and implemented.

- Once gullies are formed huge investment are required to rehabilitate the gully, therefore, prevention of gully erosion is better than gully stabilization. 


\section{Acknowledgements}

Not applicable' for that section

\section{Authors' contributions}

Corresponding author $\mathrm{Mr} \mathrm{GH}$ has worked on data collection and analysis. Co author $A B$ has worked on organization, edition and correction of the manuscript. Both authors read and approved the final manuscript.

\section{Funding}

Not applicable' for that section

\section{Availability of data and materials}

Applicable' in this section. All data generated or analysed during this study are included in this published article.

\section{Competing interests}

Authors of this research have no conflict of interest. Also the authors need to ensure that they are responsible for any conflict of interest that may arise. Also the researchers have not received any fee for patents of the manuscript. Concerning non financial computing interest the authors encourage the manuscript has significant value for intellectual and/or academic purposes on the fields.

\section{Author details}

${ }^{1}$ Department of Natural Resource Management, College of Agriculture, Dilla University, Dilla, Ethiopia. ${ }^{2}$ Geography and Land Resource Management, Centre for Food Security Studies; College of Development Studies, Addis Ababa University, Addis Ababa, Ethiopia. ${ }^{3}$ Water and Land Resource Centre, Addis Ababa University, Addis Ababa, Ethiopia.

\section{Received: 3 July 2019 Accepted: 20 November 2019}

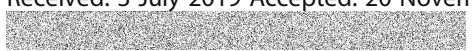

\section{References}

Abdurrahman Uyu (2012) Socio-economic status and farmers' perception towards area closure. The case of Lebu Koromo kebele, (unpublished paper).

Ayenew T (2007) Water management problems in the Ethiopian rift: challenges for development. J Afr Earth Sci 48:222-236

Bekele B, Wu W, Legesse A, Temesgen H, Yirsaw E (2018) Random and systematic land use/land cover transitions in semi-arid landscapes of Ethiopian Central Rift Valley Lakes Region (East Africa). Appl Ecol Environ Res 16:3993-4014

Bewket W (2007) Soil and water conservation intervention with conventional technologies in northwestern highlands of Ethiopia: acceptance and adoption by farmers. Land Use Policy 24(2):404-416

Boardman J, Poesen J, Evans R (2003) Socio-economic factors in soil erosion and conservation. Environ Sci Pol 6(1):1-6

Cochran WG (1977) Sampling techniques, 3d edn. Wiley, New York

CRSPT U (2000) Amhara National Regional State food security research assessment report. University of Hawai'i, Hawai'i

Demeke AB (2003). Factors influencing the adoption of soil conservation practices in North western Ethiopia. Discussion Papers, Institute of Rural Development University of Goettingen (Germany).

Dotterweich M (2015). The history of soil erosion: Interpreting historical sources, buried soils and colluvial sediments as archives of past soil erosion and human-environment interactions in the Longue Durée. Geophysical Research Abstracts vol.17; In EGU General Assembly Conference Vienna, Austria.

El-Swaify SA (1994). State of the-art for assessing soil and water conservation needs and technologies. In Napier TI, Camboni SM, El-Swaify SA (eds). Adopting conservation on the farm. An international perspective on the socio-economics of soil and water conservation society, Ankeny, IA. p. 13-17

EOSA/ Ethio-Organic Seed Action (2007) Dead line survey of Dendi. Hawasa Zuriya and Hetosa districts of Ethiopia. Ethio- Organic seed action in collaboration with centre of genetic resource Netherland. Retrieved from http://www.louisbolk.org/downloads/2129.pdf

FAO (2006) World reference base for soil, first update 2007, World Soil Resources Reports No. 103, Rome, p. 97-107.

Faulkner H, Alexander R, Teeuw R, Zukowskyj P (2004) Variations in soil dispersivity across a gully head displaying shallow sub-surface pipes, and the role of shallow pipes in rill initiation. Earth Surface Process Landforms J Br Geomorphol Res Group 29(9):1143-1160
FOTG (2002) Estimating soil loss from gully erosion. Section1, USA department of agriculture natural resource conservation services. Retrieved from https:// efotg.sc.egov.usda.gov/references/public/MO/gully-ephemeraerosion

Frankl A (2012) Gully development and its spatio-temporal variability since the late 19th century in the northern Ethiopian highlands. Afrika Focus 25(2)

Frankl A, Nyssen J, De Dapper M, Deckers J, Poesen J (2010) Dynamics of gully and river channel erosion in Northern Ethiopia: diachronic analysis of terrestrial photographs. Meded Zitt Koninklijke Academie Overzeese Wetenschappen 56(3):265-276

Gebrehiwet KB (2004) Land use and land cover changes in the central highlands of Ethiopia: the case of Yerer Mountain and its surroundings. Unpublished MSc. Project Report

Gessesse D, Gizaw AK, Hurni H (2009) Assessment of soil erosion and soil conservation practices in Angereb watershed, Ethiopia: technological and land user context. Biophysical and socio-economic frame conditions for the sustainable management of natural resources: book of abstracts, 52-52

Hurni $H$ (1988) Degradation and conservation of the resources in the Ethiopian highlands. Mt Res Dev:123-130

Ionita I, Fullen MA, Zgłobicki W, Poesen J (2015). Gully erosion as a natural and human-induced hazard; J Nat Hazards 79.

Jahantigh M, Pessarakli M (2011) Causes and effects of gully erosion on agricultural lands and the environment. Commun Soil Sci Plant Anal 42(18): 2250-2255

Jones H, Clough P, Hock B, Phillips C (2008) Economic costs of hill country erosion and benefits of mitigation in New Zealand: review and recommendation of approach. SCION, New Zealand

Konana C, Gachene C, Mburu D, Mureithi S, Gicheru P, Khalif Z (2017) Drivers of gully erosion: case study. International Journal of Social Science and Technology, Narok

Marzolff I, Poesen J, Ries JB (2011) Short to medium-term gully development: human activity and gully erosion variability in selected Spanish gully catchments. Landform Anal 17:111-116

Mechal A, Wagner T, Birk S (2015) Recharge variability and sensitivity to climate: the example of Gidabo River basin, Main Ethiopian rift. J Hydrol Reg Stud 4 : 644-660

MoWR/Federal Democratic Republic of Ethiopia Ministry of Water Resources (2009) Annual.

Moges A, Holden NM (2008) Estimating the rate and consequences of gully development, a case study of Umbulo catchment in southern Ethiopia. Land Degrad Dev 19(5):574-586

Parikh SJ, James BR (2012) Soil: The Foundation of Agriculture. Nat Educ Knowle 3:2. http://www.nature.com/scitable/knowledge/library/soil-the-foundationofagriculture-84224268

Pathak P, Wani SP, Sudi R (2005) Gully control in SAT watersheds. Global theme on agroecosystems report no 15

Pimentel D, Burgess M (2013) Soil erosion threatens food production. Agriculture 3(3):443-463

Poesen J, Nachtergaele J, Verstraeten G, Valentin C (2003) Gully erosion and environmental change: importance and research needs. Catena 50(2-4):91133

Poesen J, Torri DB, Vanwalleghem T (2011) Gully erosion: procedures to adopt when modelling soil erosion in landscapes affected by gullying. In: Handbook of erosion modelling. Blackwell Publishing Ltd., Chichester, pp 360-386

Rowntree KM (1991) Morphological characteristics of gully networks and their relationship to host materials, Baringo District, Kenya. GeoJournal 23(1):19-27

Shiferaw B, Holden S (1999) Soil erosion and smallholders' conservation decisions in the highlands of Ethiopia. World Dev 27(4):739-752

Stefanovits P, Várallyay G (1992) State and management of soil erosion in Hungary. In: proceedings of the soil Erosion and remediation workshop, UScentral and eastern European agro-environmental program. Budapest, pp 79-95

Stout BA (1965) Soil erosion by water, some measures for its control on cultivated lands. FAO Agric. Dev. Paper no. 81. FAO, Rome

Taddese G (2001) Land degradation: a challenge to Ethiopia. Environ Manag 27(6):815-824

Tamene L, Vlek PL (2008) Soil erosion studies in northern Ethiopia. In land use and soil resources. Springer, Dordrecht, pp 73-100

Tebebu TY, Abiy AZ, Zegeye AD, Dahlke HE, Easton ZM, Tilahun SA, ... and Steenhuis TS (2010) Surface and subsurface flow effect on permanent gully 
formation and upland erosion near Lake Tana in the northern highlands of Ethiopia. Hydrol Earth Syst Sci 14(11):2207-2217

ul Rasool I, Khera KL, Gul F (2011) Proliferation of gully erosion in the submontane Punjab, India. Asian J Sci Res 4:287-301

Valentin C, Poesen J, Li Y (2005) Gully erosion: impacts, factors and control. Catena 63(2-3):132-153

Vijith H, Dodge-Wan D (2019) Modelling terrain erosion susceptibility of logged and regenerated forested region in northern Borneo through the analytical hierarchy process (AHP) and GIS techniques. Geoenviron Disasters 6(1):8

WAO (2011) Woreda agricultural office report of the study area

Zachar D (1982) Soil erosion. Dev Soil Sci 10:15-29. Retrieved from http://journals. sagepub.com/doi/abs/10.1177

Zgłobicki W, Baran-Zgłobicka B, Gawrysiak L, Telecka M (2015) The impact of permanent gullies on present-day land use and agriculture in loess areas ( $E$. Poland). Catena 126:28-36

\section{Publisher's Note}

Springer Nature remains neutral with regard to jurisdictional claims in published maps and institutional affiliations.

\section{Submit your manuscript to a SpringerOpen ${ }^{\odot}$ journal and benefit from:}

- Convenient online submission

- Rigorous peer review

- Open access: articles freely available online

- High visibility within the field

- Retaining the copyright to your article

Submit your next manuscript at $\boldsymbol{\nabla}$ springeropen.com 